\title{
Supplementary UV radiation on eggplants indirectly deters Bemisia tabaci settlement without altering the predatory orientation of their biological control agents Nesidiocoris tenuis and Sphaerophoria rueppellii
}

\author{
Inés Prieto-Ruiz ${ }^{1} \cdot$ Elisa Garzo ${ }^{1}$ Aránzazu Moreno ${ }^{1,3} \cdot$ Beatriz Dáder $^{2} \cdot$ Pilar Medina $^{2,3} \cdot$ Elisa Viñuela $^{2,3}$. \\ Alberto Fereres ${ }^{1,3}$ iD
}

Received: 7 May 2018 / Revised: 11 February 2019 / Accepted: 7 March 2019 / Published online: 4 April 2019

c) Springer-Verlag GmbH Germany, part of Springer Nature 2019

\begin{abstract}
Ultraviolet (UV) radiation that reaches the earth surface has increased substantially in the past decades, altering insect-plant interactions by directly affecting herbivores behavior or indirectly by modifying plant chemistry and morphogenesis. We evaluated the indirect effect of supplementary UV radiation under glasshouse conditions on Bemisia tabaci settlement, eggplant (Solanum melongena L.) production and its effects on the flight activity of Nesidiocoris tenuis and Sphaerophoria rueppellii. Eggplants were daily radiated with different supplemental UV treatments, A +/B +, A-/B + or A -/B -, during 30,60 or 90 min for 21 days. The whitefly settlement was assessed immediately after the UV treatments or after 18 extra days on plants kept under regular glasshouse conditions with no further supplemental UV radiation. The number of whitefly settled on plants was counted after 2, 6, 24 and $48 \mathrm{~h}$. Supplementary UV radiation reduced whitefly settlement for all exposure times with alterations on the morphology and increased nitrogen and amino acid content of eggplants, mainly after $90 \mathrm{~min}$ of UV radiation exposition. When plants were allowed to recover under regular light conditions, growth traits were similar, and whiteflies showed no preference. Fruit parameters were not negatively altered by supplementary UV radiation. Natural enemy captures per sticky trap were more abundant under $\mathrm{A}-/ \mathrm{B}+$ and $\mathrm{A}+\mathrm{B}+$ conditions; however, indirect host preference tests indicated no differences among treatments. In conclusion, supplementary UV radiation could be used to reduce whitefly infestation in glasshouses at the early stages of plant development without detrimental effects on crop yield or beneficial orientation.
\end{abstract}

Keywords UV $\cdot$ Whitefly $\cdot$ Natural enemies $\cdot$ Host plant resistance $\cdot$ Fruit production $\cdot$ Plant growth

\section{Key message}

Communicated by T. Haye.

Alberto Fereres

a.fereres@csic.es

1 Departamento de Protección Vegetal, Instituto de Ciencias Agrarias (ICA-CSIC), Madrid, Spain

2 Unidad de Protección de Cultivos, Escuela Técnica Superior de Ingeniería Agronómica, Alimentaria y de Biosistemas (ETSIAAB), Universidad Politécnica de Madrid (UPM), Madrid, Spain

3 Associate Unit IVAS (CSIC-UPM): Control of Insect Vectors of Viruses in Horticultural Sustainable Systems, Madrid, Spain
- Supplemental UV radiation provokes whitefly exclusion on eggplants (BBCH 16) radiated for 30,60 or $90 \mathrm{~min}$ daily for 21 days.

- This effect is transient over time, and no whitefly exclusion could be noticed on eggplants (BBCH 21) after 18 days of no supplemental UV radiation.

- Fruit production was not altered by radiation.

- UV radiation could be an effective strategy to control whiteflies on glasshouses as it does not have any unfavorable effect on the activity of natural enemies under study. 


\section{Introduction}

Importance of ultraviolet (UV) radiation studies increased with the depletion of the ozone layer, which enhances the percentage of ultraviolet radiation that reaches the Earth's surface (Solomon 1999), a depletion that was thought to continue at least into the next mid-century. However, later predictions and protocols suggest that the ozone layer will be returning to 1980 values in the 2060s (Dhomse et al. 2018; McKenzie et al. 2007; World Meteorological Organization et al. 2018). Ultraviolet light is divided into three different wavelengths ranges, ultraviolet A (UV-A, 315-400 nm), ultraviolet B (UV-B, 280-315 nm) and ultraviolet C (UVC, 10-280 nm), which have distinct effects on plants and arthropods (Enciso et al. 2018; Johansen et al. 2011; Short et al. 2018; Vänninen et al. 2010), although UV-C radiation (lower than $290 \mathrm{~nm}$ ) does not reach at the earth's surface due to the ozone layer (Dwivedi et al. 2018). Knowledge of the impact that UV-A has on plant growth and chemistry has been loosely studied over the years. UV-A exposure enhanced the thickness of the palisade parenchyma and abaxial epidermis, epidermis thickness, cell length and induced stress routes (Johansen et al. 2011; Tezuka et al. 1994; Vänninen et al. 2010; Verdaguer et al. 2017). However, the majority of studies have focused on UV-B, which is known to inhibit photosynthetic activity, promote leaf thickening and negatively affect leaf area mainly in the epidermis of the adaxial side of the leaf (Jansen 2002). Moreover, UV-B radiation promotes changes in the mesophyll in order to protect the photosynthetic mechanisms, as well as activates the stress routes and therefore the accumulation of plant defense-related secondary metabolites (Almeida et al. 2013; González et al. 2009; Jansen 2002; Jayakumar et al. 2003; Neugart and Schreiner 2018; Paul et al. 2012; Rozema et al. 1997). This defense has been associated with increased accumulation of anti-nutritive defensive proteins, thus indirectly reducing the palatability of plants for insects (Izaguirre et al. 2007; Demukra et al. 2010; Mewis et al. 2012). Photomorphogenesis plant responses to UV-B reduce the ability of arthropods to effectively feed or reproduce (Almeida et al. 2013; Vänninen et al. 2010).

UV radiation is also known to play a major role in arthropod behavior, having a direct impact, modifying their migration patterns, take off and host plant finding ability, settlement, feeding behavior or their life cycle (Ben-Yakir and Fereres 2016; Johansen et al. 2011; Raviv and Antignus 2004). The interaction of UV-A with hemipterans and their host plants has been studied by Dáder et al. (2014). Further information on UV-arthropod interactions is available for pollinators (Foster et al. 2014) or mites (Onzo et al. 2010).

Successful Integrated Pest Management (IPM) systems on protected crops use a wide variety of control measures including physical tactics such as the use of exclusion nets or UV-blocking films (Antignus et al. 1998; Dáder et al. 2014, 2015; Díaz and Fereres 2007; Legarrea et al. $2012 \mathrm{a}, \mathrm{b})$. However, UV radiation manipulation to optimize plant growth and pest exclusion should not interfere with other strategies such as biocontrol agents frequently used inside the protected crop. Vision studies on hymenopterans suggest spectral efficiency at $520 \mathrm{~nm}$, and in the UV region (Mellor et al. 1997), photoreceptors shared with hemipteran crop pests such as aphids and whiteflies (Coombe 1982; Kirchner et al. 2005; Mound 1962). Aphid and whitefly parasitoids are attracted to high UV radiation, but they can perform well in UV-filtered environments (Chiel et al. 2006; Chyzik et al. 2003; Dáder et al. 2015; Doukas and Payne 2007; Legarrea et al. 2014). However, there is not a large body of literature on the direct effect of UV-B on predators (Legarrea et al. 2012b), but Dáder et al. (2015) found compatibility of deficient-UV conditions with foraging success of Sphareophoria rueppellii Weidemann (Diptera: Syrphidae), a natural enemy of aphids, psyllids and whiteflies, implying that predators might use additional cues to find their hosts. No data on the effects of UV radiation are available for the mirid Nesidiocoris tenuis Reuter (Hemiptera: Miridae), a zoophytophagous predator also feeding on whiteflies, and further knowledge is needed in this area. As a whole, natural enemies that rely solely or most on their vision to find a host may see their activity disturbed or compromised under low-UV radiation environments.

In the last 30 years, Bemisia tabaci Gennadius (Hemiptera: Aleyrodidae) has become the most important crop pest in the Easter Mediterranean region, mainly in greenhouse production systems (Oliveira et al. 2001). Whitefly importance as a pest arises from its ability to induce direct damage from feeding, but also indirectly as vectors for plant viruses (Matthews et al. 2002) and by producing honeydew, the perfect growing medium for the black mildew (Oliveira et al. 2001). Chemical control against whiteflies encounters several problems: whiteflies low sensibility to the commonly used pesticides, their rapid generation of resistance and the presence of different development stages within the same plant as well as the migration to the neighbor crop. Therefore, there is a need of implementing new control strategies and the use of UV light seems promising.

In the present study, we investigated the application of different time exposures and combinations of supplementary UV-A and UV-B radiation on eggplant Solanum melongena L. as a method to deter whitefly settlement. Furthermore, we assessed plant morphological and chemical changes due to supplemental UV radiation on the settlement of $B$. tabaci as well as its impact on the activity of natural enemies $S$. rueppellii and $N$. tenuis. 


\section{Materials and methods}

\section{Plant material and insect species}

Experiments were conducted at the Institute of Agricultural Sciences of the Spanish National Research Council (ICA-CSIC, Madrid, Spain) $\left(40^{\circ} 26^{\prime} 23^{\prime \prime} \mathrm{N}, 3^{\circ} 41^{\prime} 14^{\prime \prime} \mathrm{W}\right)$ under glasshouse conditions $\left(24: 18 \pm 2{ }^{\circ} \mathrm{C}\right.$ day/night temperature; $14: 10$-h light/dark photoperiod; $60-70 \% \mathrm{RH}$ ) from spring 2016 to summer 2017. Glasshouse dimensions were $6.4 \times 6 \times 4.5 \mathrm{~m}(\mathrm{~L} \times \mathrm{W} \times \mathrm{H})$, and light transmission properties of outer surface were average $50 \%$ PAR, $15 \%$ UV-A and 10\% UV-B. Seeds of eggplant (S. melongena L. cv Black Beauty) (Ramiro Arnedo SA, La Rioja, Spain) were sown in Petri dishes and then transplanted individually into pots according to growth with a 1:2 mixture of vermiculite (Asfaltex S.A., Barcelona, Spain) and soil substrate (GoV4, Jiffy International, AS, Norway). Each plant was watered using 20-20-20 (N-P-K) Nutrichem fertilizer (Miller Chemical \& Fertilizer Corp., Pennsylvania, USA) at a dose of $1 \mathrm{~g}^{-1}$. Bemisia tabaci biotype Q was kindly provided by Prof. Dr. Enrique Moriones (IHSM-La Mayora-CSIC, Málaga, Spain) in 2007. The population was reared on eggplants in a glasshouse under the conditions stated above. Whiteflies were synchronized prior the bioassay to guarantee age homogeneity at the time of the experiment (approximately 1 week old). Syrphid $S$. rueppellii pupae (BioNostrum SL, Alicante, Spain) were kept under controlled conditions $\left(20^{\circ} \mathrm{C}\right.$ temperature; $75 \pm 5 \% \mathrm{RH}, 16: 8$-h light/dark photoperiod) until adult emergence and then fed with water, pollen and sugar for 4 days when individuals were used in the experiments. Mirid N. tenuis nymphs (Agrobio SL, Almería, Spain) were kept 1 week under controlled conditions $\left(25 \pm 2{ }^{\circ} \mathrm{C}\right.$ temperature; $75 \pm 5 \% \mathrm{RH}, 16: 8$-h light/dark photoperiod) until adult emergence, and 72-h-old individuals were used in the experiments.

\section{UV radiation treatments}

Three different combinations of UV-A and UV-B radiations were tested: $\mathrm{A}+/ \mathrm{B}+, \mathrm{A}-/ \mathrm{B}+$ and $\mathrm{A}-/ \mathrm{B}-$ (control). UV-A radiation was supplied by fluorescent tubes Philips TL-K $40 \mathrm{~W} / 10-\mathrm{R}$ and UV-B radiation by fluorescent tubes Philips TL 40 W/12 RS (Royal Philips Electronics, Amsterdam, The Netherlands). The three radiations treatments were obtained by covering the tubes with filters to block specific wavelengths. UV-A tubes were wrapped with highdensity polyethylene (HDPE) $0.2 \mathrm{~mm}$ thickness film (Solplast SA, Murcia, Spain) cutting off wavelengths $<400 \mathrm{~nm}$ to obtain $\mathrm{A}$ - treatment, while $\mathrm{A}+$ treatment was obtained with unwrapped UV-A tubes. UV-B tubes were covered with stabilized polyester film Autostat CT14 $0.1 \mathrm{~mm}$ thickness (MacDermid Autotype Ltd., Wantage, UK) cutting off wavelengths $<320 \mathrm{~nm}$ to obtain B-treatment. UV-B tubes were covered with cellulose diacetate film Ultraphan $0.1 \mathrm{~mm}$ thickness (Modulor GmbH, Berlin, Germany) cutting off wavelengths $<295 \mathrm{~nm}$ (UV-C radiation) to obtain $\mathrm{B}+$ treatment. Fluorescent tubes (4 tubes of UV-A and 2 of UV-B) were mounted on metallic frames hanging $1 \mathrm{~m}$ above plant canopy. Filters were replaced every week. During UV light treatments, high-pressure sodium-vapor PAR lamps Philips SON-T 400 W E E40 1SL/12 (Royal Philips Electronics, Amsterdam, The Netherlands) hanging $1 \mathrm{~m}$ above plant canopy were also turned on.

\section{Eggplant exposure to UV treatments}

Eggplants were located inside a set of three cages of $1 \times 1 \times 1 \mathrm{~m}(\mathrm{~L} \times \mathrm{H} \times \mathrm{W})$ covered with a $95-\mu \mathrm{m}$ Nytal fine cloth (Maissa SA, Barcelona, Spain) to allow ventilation. Above each cage, one of the corresponding UV treatments $(\mathrm{A}+/ \mathrm{B}+, \mathrm{A}-/ \mathrm{B}+$ or $\mathrm{A}-/ \mathrm{B}-)$ were applied for 21 days on 21-day-old eggplants (BBCH 11) (Acosta-Quezada et al. 2016) with exposure times of either 30,60 or $90 \mathrm{~min}$ daily (Fig. 1). Tubes were suspended at $30 \mathrm{~cm}$ high above
Fig. 1 Timeline of the experimental design, showing the two different settlement assays and fruit harvests

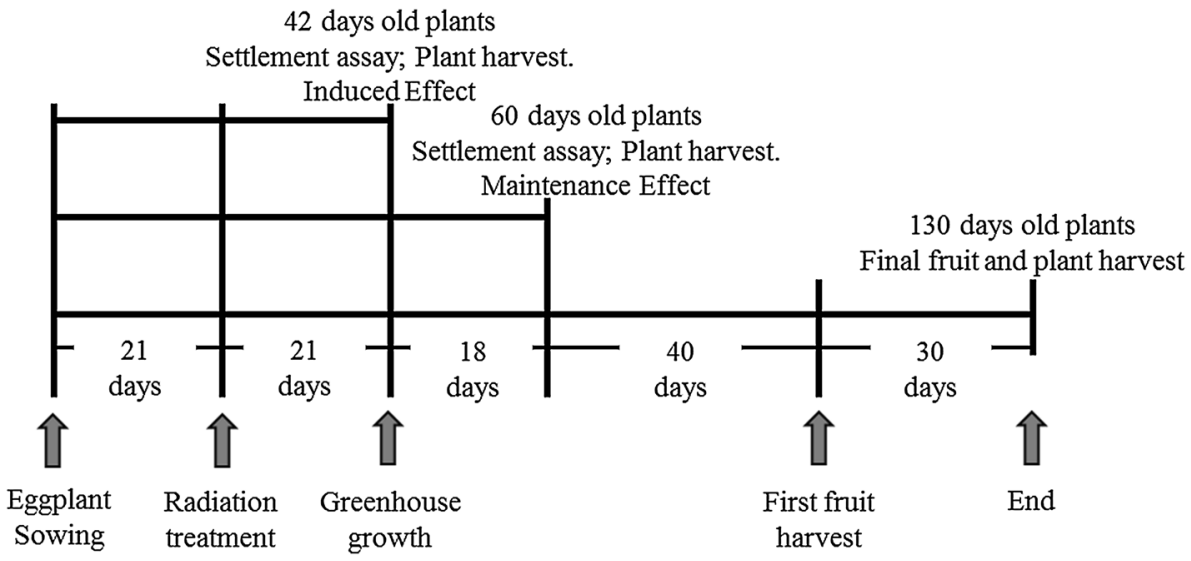


cages and switched on and off with no gradual transition. A piece of UV-blocking polyethylene film was placed vertically separating the cages to filter the UV radiation coming from nearby lamps and to avoid interferences between treatments. Plants were rotated inside the cage as well as the cages within the glasshouse to avoid positional effects. After UV exposure, eggplants were either readily used for experiments (42-day-old plants, BBCH 16) or kept under regular glasshouse light conditions for 18 more days without supplemental UV treatment before experiments (60-day-old plants, BBCH 21) (Fig. 1). Irradiance received by the plants was measured punctually twice a week at solar zenith at canopy level with an ALMEMO 25904S radiometer (Ahlborn GmbH, Holzkirchen, Germany) for UV spectrum and a MQ-100 quantum integral sensor (Apogee Instruments Inc., Utah, USA) for PAR light (Table 1).

\section{Bemisia tabaci indirect effect experiments}

Eggplants from each of the three UV radiation treatments described above, $\mathrm{A}+/ \mathrm{B}+, \mathrm{A}-/ \mathrm{B}+$ or $\mathrm{A}-/ \mathrm{B}-$, were alternately placed forming an equidistant circle inside mesh cages of $1 \times 1 \times 1 \mathrm{~m}(\mathrm{~L} \times \mathrm{H} \times \mathrm{W})$. Two hundred B. tabaci adults were released in black glass tubes placed on a flight platform centered hanging $25 \mathrm{~cm}$ from the ceiling inside the cages without artificial light. Whiteflies settled on eggplants were counted after 2, 6, 24 and $48 \mathrm{~h}$. Whiteflies settled on the abaxial side of leaves were counted with a mirror not to disturb the insects. To minimize bias from the sunlight, whiteflies were released at zenith hour and cages were rotated after each counting. Two types of assays with eggplants of different age were performed: (1) 42-day-old plants $(\mathrm{BBCH} 16)$ radiated according to treatments $\mathrm{A}+/ \mathrm{B}+$, $\mathrm{A}-/ \mathrm{B}+$ or $\mathrm{A}-/ \mathrm{B}-$ during 30,60 or 90 min daily for 21 days and used right after UV exposure ended (induced effect), as well as (2) 60-day-old plants (BBCH 21) radiated for 30 or 60 min daily during 21 days and kept for 18 more days under regular glasshouse light conditions until whitefly release (maintenance effect) (Fig. 1). The reason behind leaving a period between supplemental UV exposure and whitefly release was to study the persistence of the UV effect on plants once flowers start appearing, and there is a shift in resource allocation and decreased risk to virus damage. Each treatment and exposure time was replicated six times (six cages). The number of plants per treatment for the assay with 42-day-old eggplants (BBCH 16) was 3 (total number of plants per cage, 9) and for the assay with 60-day-old plants (BBCH 21) was 2 (total number of plants per cage, 6). The number of plants per cage was reduced when plants were larger to avoid competition for light.

\section{Plant processing after whitefly assays}

Forty-eight hours after whitefly release, infested plants were processed and leaves were separated from the stem. Stem length was measured and leaves counted (42-dayold (BBCH 16, induced effect): $n=18 ; 60$-day-old (BBCH 21; maintenance effect): $n=12$ ). After each plant part was weighed, some samples were dried at $60^{\circ} \mathrm{C}$ to measure dry weight (42-day-old (BBCH 16): $n=6,60$-day-old (BBCH 21): $n=6$ ) and the rest were maintained at $-80^{\circ} \mathrm{C}$ for further analyses. For 42-day-old plants (BBCH 16), the area of the fifth leaf was measured $(n=7)$. In order to be able to calculate specific leaf area (SLA), leaf dry matter content (LDMC) and leaf thickness (LF) [calculated using the formulas described in Vile et al. (2005) $(n=12)]$, for 60-dayold plants (BBCH 21), all the leaves in the plant were measured; all areas were calculated using ImageJ $(n=12)$.

\section{Fruit harvesting experiment}

Eggplants from each radiation treatment supplemented during 30 or 60 min daily for 21 days never exposed to whiteflies were allowed to grow for 88 extra days after UV

Table 1 Mean \pm SE instantaneous irradiance measured at canopy level inside the experimental cages during the radiation of eggplants with lights on and off throughout the duration of the experiments, glasshouse without any artificial light and outdoors of the glasshouse

\begin{tabular}{|c|c|c|c|c|c|c|}
\hline & \multicolumn{6}{|c|}{ Inside experimental cages } \\
\hline & \multicolumn{3}{|l|}{ Lights on } & \multicolumn{3}{|l|}{ Lights off } \\
\hline & UV-A Wm ${ }^{-2}$ & UV-B Wm ${ }^{-2}$ & PAR $\mu \mathrm{mol} \mathrm{m}{ }^{-2} \mathrm{~s}^{-1}$ & UV-A Wm ${ }^{-2}$ & UV-B Wm ${ }^{-2}$ & PAR $\mu \mathrm{mol} \mathrm{m}{ }^{-2} \mathrm{~s}^{-1}$ \\
\hline Treatment $\mathrm{A}-/ \mathrm{B}-$ & $0.56 \pm 0.05$ & $0.009 \pm 0.000$ & $175.17 \pm 7.65$ & $0.42 \pm 0.07$ & $0.005 \pm 0.000$ & $58.30 \pm 9.67$ \\
\hline Treatment $\mathrm{A}-/ \mathrm{B}+$ & $0.61 \pm 0.06$ & $0.120 \pm 0.007$ & $179.42 \pm 9.81$ & $0.48 \pm 0.09$ & $0.004 \pm 0.000$ & $61.75 \pm 12.39$ \\
\hline \multirow[t]{3}{*}{ Treatment $\mathrm{A}+/ \mathrm{B}+$} & $1.38 \pm 0.07$ & $0.130 \pm 0.008$ & $181.03 \pm 8.91$ & $0.51 \pm 0.08$ & $0.004 \pm 0.000$ & $63.70 \pm 9.53$ \\
\hline & & \multicolumn{5}{|c|}{ Outside experimental cages } \\
\hline & & \multicolumn{2}{|l|}{ UV-A Wm ${ }^{-2}$} & \multicolumn{2}{|l|}{ UV-B Wm ${ }^{-2}$} & PAR $\mu \mathrm{mol} \mathrm{m}{ }^{-2} \mathrm{~s}^{-1}$ \\
\hline Glasshouse & \multicolumn{3}{|c|}{$1.55 \pm 0.18$} & \multicolumn{2}{|l|}{$0.011 \pm 0.001$} & $163.89 \pm 20.94$ \\
\hline Outdoors & \multicolumn{3}{|c|}{$34.45 \pm 2.77$} & \multicolumn{2}{|l|}{$0.735 \pm 0.015$} & $1371.46 \pm 27.68$ \\
\hline
\end{tabular}


exposure under regular glasshouse light conditions (Fig. 1). Stem length, number of leaves and flowers, leaf area and fresh weight were analyzed $(n=10)$. The first harvest occurred 100 days after sowing, and from then we harvested regularly according to fruit growth. Length, diameter and fresh weight of commercial fruits (heavier than 100 grams) were measured. Harvest index used to quantify the yield of a crop species versus the total amount of biomass that has been produced was calculated by dividing total fresh weight of commercial fruits per plant by plant shoot tissue biomass $(n=10)$. Lastly, dry weight of each plant was measured $(n=10)$.

\section{Direct flight experiments with natural enemies}

With the aim to test whether flight height of beneficial arthropods was influenced by UV radiation, we placed one sticky yellow trap $(80 \times 25 \mathrm{~cm})$ vertically inside each mesh cage of $1 \times 1 \times 1 \mathrm{~m}(\mathrm{~L} \times \mathrm{H} \times \mathrm{W})$, at $10 \mathrm{~cm}$ high from the base and separated $6 \mathrm{~cm}$ from the side wall. This trap was marked each $10 \mathrm{~cm}$ from 10 to $90 \mathrm{~cm}$ height and used alone for S. rueppellii. In the case of $N$. tenuis, one green bean with Ephestia kuehniella Zeller (Lepidoptera: Pyralidae) eggs (Agrobio SL, Almería, Spain) used as attractant was attached horizontally each $10 \mathrm{~cm}$ height of the trap. Ten S. rueppellii or fifty $N$. tenuis adults were released in a black plastic cage placed on a flight platform at $30.5 \mathrm{~cm}$ high from the base of the cage. This platform was located at $10 \mathrm{~cm}$ from the opposite wall to the sticky trap to maximize distance to target $(84 \mathrm{~cm})$. A set of three mesh cages were used, each one under one of the three radiation treatments, $\mathrm{A}+/ \mathrm{B}+, \mathrm{A}-/ \mathrm{B}+$ or $\mathrm{A}-/ \mathrm{B}-$, during the whole duration of each experiment. Syrphids were counted after 1, 2 and $3 \mathrm{~h}(n=10)$ and mirids after 2, 6 and $8 \mathrm{~h}(n=6)$, taking into account the height of each capture. To minimize bias from the sunlight, treatment position was randomized each experiment.

\section{Nesidiocoris tenuis indirect effect experiments}

Three-week-old eggplants radiated for 60 min daily during 21 days with either one of the three UV radiation treatments, $\mathrm{A}+/ \mathrm{B}+, \mathrm{A}-/ \mathrm{B}+$ or $\mathrm{A}-/ \mathrm{B}-$, were alternately placed forming an equidistant circle inside mesh cages of $1 \times 1 \times 1 \mathrm{~m}$ $(\mathrm{L} \times \mathrm{H} \times \mathrm{W})$. Fifty $N$. tenuis adults were released in a black plastic cage placed on a flight platform centered at $30.5 \mathrm{~cm}$ high from the base of the cage without any artificial light. Mirids settled on eggplants were counted after 2, 24 and $48 \mathrm{~h}$. For each exposure time, the experiment was replicated six times (six cages). The number of plants per treatment was 3 (total number of plants per cage, 9).

\section{Plant biochemical analysis of eggplant leaves}

To analyze carbon, nitrogen as well as macro- and microelements, air-dried leaves $\left(60{ }^{\circ} \mathrm{C}\right)$ of plants used for the whitefly orientation assays were grounded and prepared for the analyses $(n=6)$. Total $\mathrm{C}$ and $\mathrm{N}$ content were measured by Dumas direct combustion method using an elemental analyzer (LECO). Soluble sugars and free amino acids were obtained following the extraction, manipulation and mass spectrometric analysis of samples from an adapted protocol detailed on Corrales et al. (2014). Non-detectable compounds may be due to non-existence in the sample. However, this could also be due to poor samples quality to be quantified by mass spectrometry, missing analysis transition or interferences on the analysis.

\section{Statistical analysis}

Statistical analyses were performed with the IBM Statistics SPSS v.23.0 package for Mac (IBM Co., New York, USA). Numbers of B. tabaci settled were analyzed by GLM repeated measures (SPSS) with HDS Tukey post hoc $(p \leq 0.05)$ to study the main effects: UV light treatment and time. A repeated factor, within-subject factor (dependent variable, time), and a main fixed factor, between-subject factor (UV light treatment), were defined in the model. Fresh and dry weights, morphologic parameters, carbon and nitrogen contents, soluble carbohydrates and free amino acids of the plants were analyzed by one-way ANOVA for normal and homoscedastic data with post hoc HDS Tukey or by nonparametric Wilcoxon test and Kruskal-Wallis $H$ analysis for non-normal or heteroscedastic data comparison with post hoc Steel-Dwass $(p<0.05)$. Direct and indirect effects experiments with natural enemies $N$. tenuis and $S$. rueppellii were analyzed by one-way ANOVA with repeated measures followed by LSD $(p<0.05)$. Additionally, data were also analyzed taking into account capture height. If data did not follow a normal distribution, they were transformed with $\arcsin \sqrt{ }(x / 100)$, in order to decrease heteroscedasticity. Nonparametric Wilcoxon and Kruskal-Wallis $H$ test or Mann-Whitney $U$ test was used when data did not follow criteria for parametric methods. Figure 1 is made using PowerPoint and Figs. 2 and 3 using Excel.

\section{Results}

\section{Whitefly settlement}

Supplementary UV-B triggered a significantly reduction in the settlement rate of whiteflies on 42-day-old (BBCH 16) eggplants (induced effect) radiated during 30,60 and 90 min daily for 21 days with no gap between UV exposure 

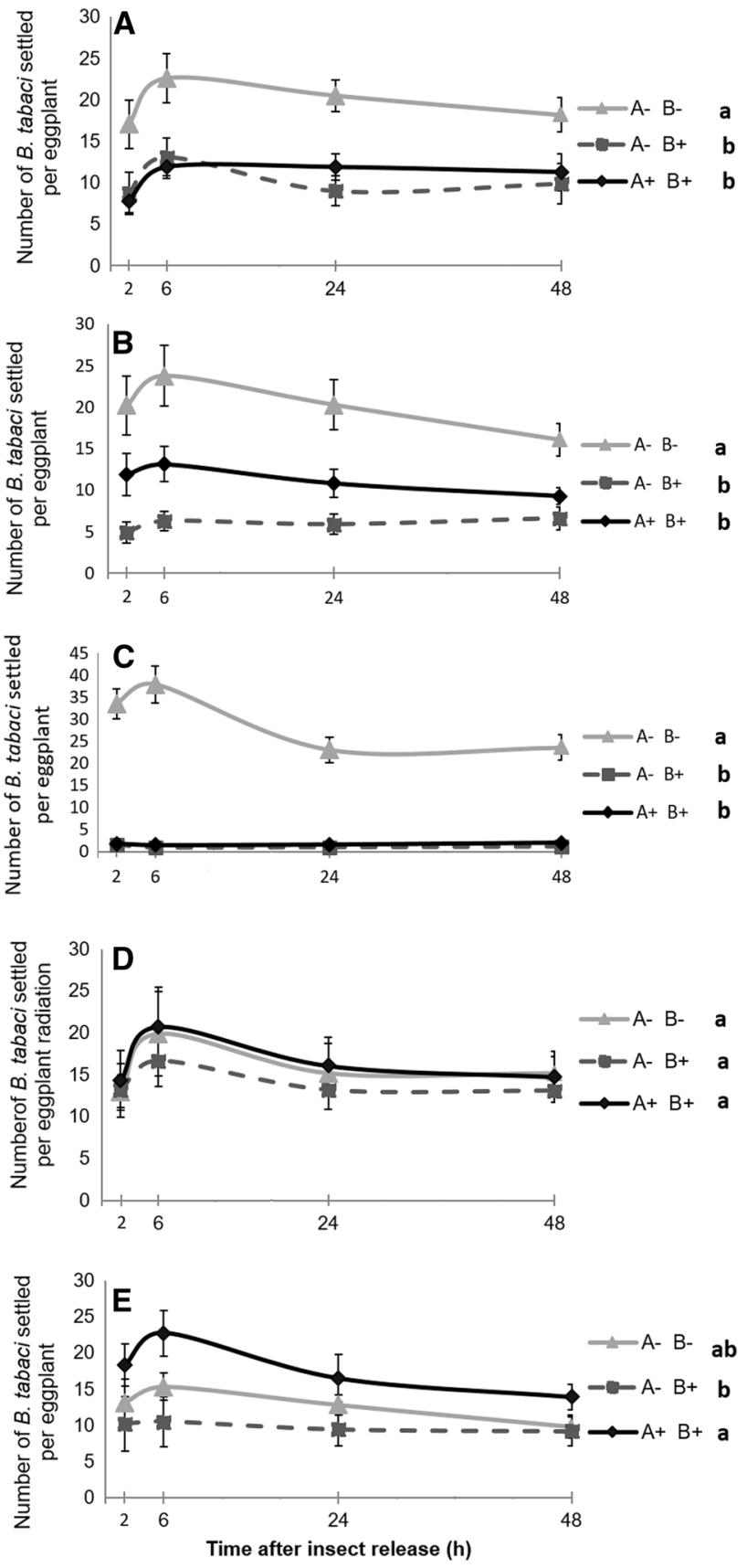

Fig. 2 Mean \pm SE number of whitefly Bemisia tabaci settled per eggplant previously radiated with one of the three UV regimes $(\mathrm{A}+\mathrm{B}+$, $\mathrm{A}-/ \mathrm{B}+$ or $\mathrm{A}-/ \mathrm{B}-$ ) for 30,60 or 90 min daily during 21 days in the indirect effect experiment. Two plant ages were considered, (1) 42-day-old plants (BBCH 16; induced effect), radiated for 30 (a), 60 (b) and $90 \mathrm{~min}$ (c) and used right after UV exposure ended for the experiment, and (2) 60-day-old plants (BBCH 21; maintenance effect), radiated for $30(\mathbf{d})$ or $60 \mathrm{~min}(\mathbf{e})$. Means with different letters are significantly different $(p<0.05)$

and insect release. Treatments $\mathrm{A}-/ \mathrm{B}+$ and $\mathrm{A}+/ \mathrm{B}+$ caused a decrease in the number of whiteflies settled on plants compared to control plants A -/B - [30 min: $F=9.007$,
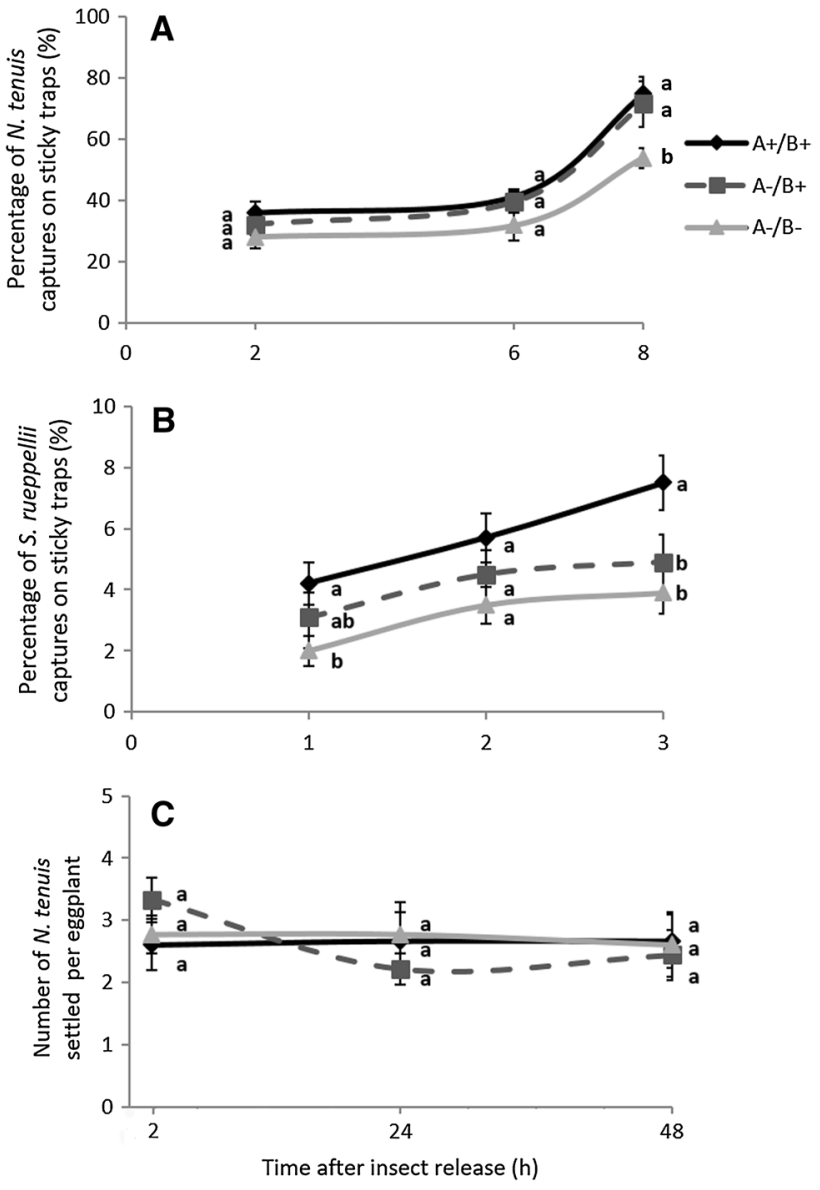

Fig. 3 Mean \pm SE rate (\%) of mirid Nesidiocoris tenuis total captures per sticky trap (a) and syrphid Sphaerophoria rueppellii total captures per sticky trap (b) under the three UV light regimes $(\mathrm{A}+/ \mathrm{B}+$, $\mathrm{A}-/ \mathrm{B}+$ or $\mathrm{A}-/ \mathrm{B}-)$ in the direct experiment. Mean \pm SE number of total $N$. tenuis (c) settled per eggplant previously radiated with one of the three UV light regimes for 60 min daily during 21 days in the indirect effect experiment. Means with different letters stand for statistical differences $(p<0.05)$

$d f=2(51), p<0.001$ (Fig. 2a); 60 min: $F=13.823$, $d f=2(51), p<0.001$ (Fig. 2b); 90 min: $F=132.052$, $d f=2(51), p<0.001$ (Fig. 2c)]. With regard to 60-day-old (BBCH 21) eggplants (maintenance effect) similarly radiated for 21 days but with a gap of 18 days between UV exposure and insect release, no differences were observed among daily UV treatments applied for $30 \mathrm{~min}(F=0.217$, $d f=2(45), p=0.806$ ) (Fig. 2d); however, significant differences were found between treatments $A-/ B+$ and $\mathrm{A}+/ \mathrm{B}+$ for $60 \mathrm{~min}$, with a decrease in the number of whiteflies on plants radiated with $\mathrm{A}-/ \mathrm{B}+$ compared to $\mathrm{A}+/ \mathrm{B}+(F=3.620, d f=2(45), p=0.038)$ (Fig. 2e). 


\section{Eggplant growth and physiology}

Both plant morphology and physiology were modified by supplementary UV radiation. Shoot tissue fresh weight of 42-day-old (BBCH 21) eggplants (induced effect) exposed to $A-/ B+$ for 30 or 60 min daily significantly diminished compared to control A - /B - eggplants (30 min: $F=4.078, d f=2(51), p=0.023 ; 60 \mathrm{~min}$ : $F=9.219, d f=2(51), p<0.001$ ) (Table 2). For 90-min exposure time, plants under both supplemental UV treatments $(\mathrm{A}-/ \mathrm{B}+$ and $\mathrm{A}+/ \mathrm{B}+)$ were significantly smaller compared to control A -/B - plants $(H=148.8260, d f=2$, $p<0.001$ ) (Table 2). Shoot tissue dry weight was significantly lower on $\mathrm{A}-/ \mathrm{B}+$ and $\mathrm{A}+/ \mathrm{B}+$ plants compared to control A - $/ \mathrm{B}-$ after 60 and $90 \min (60 \mathrm{~min}: F=4.623$, $d f=2(15), p=0.027 ; 90 \mathrm{~min}: H=37.5743, d f=2, p<0.001)$, although no differences were found for $30 \mathrm{~min}(F=1.253$, $d f=2(15), p=0.314$ ) (Table 2). Stem length was significantly shorter for $\mathrm{A}-\mathrm{B}+$ plants compared to control A - /B - for $90 \mathrm{~min}$, while no differences were found for 30 or 60 min (30 min: $F=0.941, d f=2(51), p=0.188 ; 60$ min: $F=1.855, d f=2(51), p=0.168 ; 90 \mathrm{~min}: F=5.355$, $d f=2(51), p=0.008)$ (Table 2). Leaf numbers were similar for all treatments. Leaf area was significantly higher for control A -/B - plants for $90 \min \left(100.97 \pm 2.70 \mathrm{~cm}^{2}\right.$ vs. $11.91 \pm 3.16 \mathrm{~cm}^{2}$ for $\mathrm{A}-/ \mathrm{B}+$ and $23.46 \pm 5.33 \mathrm{~cm}^{2}$ for $\mathrm{A}+/ \mathrm{B}+; H=22.341, d f=2(11), p<0.001)$, while no differences were found for 30 or $60 \mathrm{~min}$.

In 60-day-old (BBCH 21) eggplants (maintenance effect), the 30-min exposure did not trigger any significant

Table 2 Mean \pm SE eggplant parameters (fresh and dry weight of the shoot tissue part in grams and stem length in $\mathrm{cm}$ ) for each radiation treatment $(\mathrm{A}-/ \mathrm{B}-, \mathrm{A}-/ \mathrm{B}+$ or $\mathrm{A}+/ \mathrm{B}+)$, $\mathrm{UV}$ exposure time $(30$, 60 or 90 min daily during 21 days) and plant age (42-day-old plants difference for any measured variable (Table 2$)$. On the other hand, 60-min daily exposure of treatment $\mathrm{A}+/ \mathrm{B}+$ significantly enhanced fresh and dry weight compared to control A -/B - (Fresh weight: $F=7.96, d f=2(15), p=0.002$; Dry weight: $F=4.12, d f=2(15), p=0.037$ ) (Table 2). Stem length, number of leaves or leaf area showed no differences among treatments. On 130-day-old plants (BBCH 89) after a gap of 88 days between UV exposure and harvesting, no differences could be appreciated for any analyzed parameter (data not shown).

We also calculated specific leaf area (SLA), leaf dry matter content (LDMC) and leaf thickness (LT) on 60-day-old (BBCH 21; maintenance effect) plants, being unaffected among treatments of $30 \mathrm{~min}$. For $60 \mathrm{~min}$, SLA was significantly reduced in treatment $\mathrm{A}+/ \mathrm{B}+$ compared to control $\mathrm{A}-/ \mathrm{B}-(246.86 \pm 11.59$ on $\mathrm{A}-/ \mathrm{B}-$ vs. $198.33 \pm 8.56$ for $\mathrm{A}+\mathrm{B}+[F=5.79, d f=2(15), p=0.010)]$ and therefore LT was significantly thicker $(4 \pm 0.33 \mu \mathrm{m}$ on $\mathrm{A}+/ \mathrm{B}+\mathrm{vs}$. $5.5 \pm 0.38 \mu \mathrm{m}$ on $\mathrm{A}-/ \mathrm{B}-[F=4.717, d f=2(15), p=0.026)$ (data not shown)].

Fresh and dry weight, stem length, number of leaves and leaf area of plants radiated for 30 or 60 min were similar among UV treatments at final harvest (130-day-old (BBCH 89) plants) (data not shown).

\section{Yield components}

No differences on fruit length, diameter or weight, harvest index, total number of fruits per plant, number of commercial fruits per plant and total weight of commercial fruits

(BBCH 16; induced effect) radiated and used right after UV exposure ended for the experiment, and 60-day-old plants (BBCH 21; maintenance effect) radiated and kept for 18 more days under regular glasshouse light conditions until experiment

\begin{tabular}{llllll}
\hline Days after radiation (plant age) & UV exposure time & Treatment & Shoot fresh weight & Shoot dry weight & Stem length \\
\hline 0 days after UV exposure (42 days & $30 \mathrm{~min}$ & $\mathrm{~A}-\mathrm{B}-$ & $15.96 \pm 0.84 \mathrm{a}$ & $1.27 \pm 0.10 \mathrm{a}$ & $19.01 \pm 0.53 \mathrm{a}$ \\
old (BBCH 16) plant) & & $\mathrm{A}-\mathrm{B}+$ & $12.26 \pm 0.70 \mathrm{~b}$ & $1.12 \pm 0.16 \mathrm{a}$ & $19.41 \pm 0.77 \mathrm{a}$ \\
& & $\mathrm{A}+\mathrm{B}+$ & $14.62 \pm 1.18 \mathrm{ab}$ & $1.01 \pm 0.07 \mathrm{a}$ & $18.33 \pm 0.77 \mathrm{a}$ \\
& $60 \mathrm{~min}$ & $\mathrm{~A}-\mathrm{B}-$ & $18.51 \pm 1.23 \mathrm{a}$ & $1.48 \pm 0.20 \mathrm{a}$ & $19.00 \pm 0.55 \mathrm{a}$ \\
& & $\mathrm{A}-\mathrm{B}+$ & $11.96 \pm 0.87 \mathrm{~b}$ & $0.83 \pm 0.10 \mathrm{~b}$ & $19.92 \pm 0.54 \mathrm{a}$ \\
& & $\mathrm{A}+\mathrm{B}+$ & $16.19 \pm 1.15 \mathrm{a}$ & $1.04 \pm 0.15 \mathrm{ab}$ & $20.31 \pm 0.49 \mathrm{a}$ \\
& & $\mathrm{A}-\mathrm{B}-$ & $14.85 \pm 0.71 \mathrm{a}$ & $1.14 \pm 0.14 \mathrm{a}$ & $19.20 \pm 0.48 \mathrm{a}$ \\
& & $\mathrm{A}-\mathrm{B}+$ & $1.10 \pm 0.30 \mathrm{~b}$ & $0.36 . \pm 0.05 \mathrm{~b}$ & $16.70 \pm 0.64 \mathrm{~b}$ \\
& & $\mathrm{~A}+\mathrm{B}+$ & $4.10 \pm 0.40 \mathrm{~b}$ & $0.35 \pm 0.06 \mathrm{~b}$ & $17.47 \pm 0.65 \mathrm{ab}$ \\
18 days after UV exposure (60 days & $30 \mathrm{~min}$ & $\mathrm{~A}-\mathrm{B}-$ & $119.78 \pm 4.69 \mathrm{a}$ & $10.64 \pm 1.61 \mathrm{a}$ & $43.50 \pm 1.22 \mathrm{a}$ \\
old (BBCH 21) plant) & & $\mathrm{A}-\mathrm{B}+$ & $111.62 \pm 9.31 \mathrm{a}$ & $10.27 \pm 2.46 \mathrm{a}$ & $41.71 \pm 1.46 \mathrm{a}$ \\
& & $\mathrm{A}+\mathrm{B}+$ & $114.71 \pm 11.02 \mathrm{a}$ & $10.72 \pm 3.51 \mathrm{a}$ & $41.29 \pm 2.14 \mathrm{a}$ \\
& \multirow{2}{*}{$60 \mathrm{~min}$} & $\mathrm{~A}-\mathrm{B}-$ & $120.38 \pm 8.18 \mathrm{~b}$ & $11.39 \pm 1.31 \mathrm{~b}$ & $48.83 \pm 2.37 \mathrm{a}$ \\
& & $\mathrm{A}-\mathrm{B}+$ & $116.94 \pm 5.09 \mathrm{~b}$ & $13.14 \pm 0.44 \mathrm{ab}$ & $49.83 \pm 1.54 \mathrm{a}$ \\
& & $\mathrm{A}+\mathrm{B}+$ & $147.77 \pm 3.83 \mathrm{a}$ & $15.32 \pm 0.95 \mathrm{a}$ & $49.00 \pm 1.58 \mathrm{a}$ \\
\hline
\end{tabular}

Means with different letters within the same parameter, UV radiation time and days after radiation are significantly different $(p<0.05)$ 
per plant were found among treatments after $30 \mathrm{~min}$ of UV exposure (data not shown). For $60 \mathrm{~min}$, all parameters were unaffected except for fruit length of $\mathrm{A}-/ \mathrm{B}+$ plants, which was significantly longer compared to rest of treatments $(20.19 \pm 0.44 \mathrm{~cm}$ vs. $18.70 \pm 0.40 \mathrm{~cm}$ for $\mathrm{A}-/ \mathrm{B}-$ and $18.71 \pm 0.39 \mathrm{~cm}$ for $\mathrm{A}+/ \mathrm{B}+; H=8.748, d f=2, p=0.013)$.

\section{Biochemical responses}

\section{Carbon and nitrogen content}

On 42-day-old (BBCH 16) plant leaves (induced effect), content of carbon, nitrogen and $\mathrm{C} / \mathrm{N}$ ratio was only significantly different on plants radiated during $90 \mathrm{~min}$ as carbon content was higher on control plants $A-B-(36.77 \pm 0.25 \mathrm{~g} / 100 \mathrm{~g}$ vs. $35.29 \pm 0.40 \mathrm{~g} / 100 \mathrm{~g}$ for $\mathrm{A}-/ \mathrm{B}+$ and $34.66 \pm 0.46 \mathrm{~g} / 100 \mathrm{~g}$ for $\mathrm{A}+/ \mathrm{B}+; H=9.579, d f=2, p=0.008)$. For nitrogen, control plants $\mathrm{A}-/ \mathrm{B}-$ had a lower concentration than radiated plants $(6.94 \pm 0.10 \mathrm{~g} / 100 \mathrm{~g}$ vs. $8.053 \pm 0.22 \mathrm{~g} / 100 \mathrm{~g}$ for $\mathrm{A}-/ \mathrm{B}+$ and $7.90 \pm 0.26 \mathrm{~g} / 100 \mathrm{~g}$ for $\mathrm{A}+/ \mathrm{B}+$; $H=9.275, d f=2, p=0.003)$. C/N ratio was higher in control plants compared to radiated plants $(5.307 \pm 0.063$ vs. $4.403 \pm 0.157$ for $\mathrm{A}-/ \mathrm{B}+$ and $4.424 \pm 0.206$ for $\mathrm{A}+/ \mathrm{B}+$; $F=11.10, d f=2(15), p=0.0011)$. In the case of 60-dayold (BBCH 21) plants (maintenance effect), 30-min radiation had no impact in the macroelements or their ratio, although 60-min radiation significantly increased carbon concentration on $\mathrm{A}+/ \mathrm{B}+$ plants $(40.34 \pm 0.17 \mathrm{~g} / 100 \mathrm{~g}$ vs. $38.70 \pm 0.31 \mathrm{~g} / 100 \mathrm{~g}$ for $\mathrm{A}-/ \mathrm{B}-$ and $38.79 \pm 0.26 \mathrm{~g} / 100 \mathrm{~g}$ for $\mathrm{A}-\mathrm{B}+; F=14.554, d f=2(15), p<0.001)$.

\section{Soluble carbohydrates}

On 42-day-old (BBCH 16) plants (induced effect) radiated during $30 \mathrm{~min}$, only the concentration of D-galactose on $\mathrm{A}-\mathrm{B}+$ radiated plants significantly increased compared with $\mathrm{A}-/ \mathrm{B}-$ and $\mathrm{A}+/ \mathrm{B}+$ plants $(H=9.000 ; d f=2$; $p=0.011$ ) (Table 3). On 60-min radiated plants, D-xylitol content significantly differed among treatments $(H=12.012$; $d f=2 ; p=0.002$ ), D-galactose was significantly lower on $\mathrm{A}-/ \mathrm{B}+$ radiated plants $(H=7.604 ; d f=2 ; p=0.002)$, and $\mathrm{D}-(-)$-fructose $(H=7.685 ; d f=2 ; p=0.021)$, sucrose $(H=11.556 ; d f=2 ; p=0.003)$, D- $(+)$-trehalose $(H=8.082$; $d f=2 ; p=0.018)$ and $\mathrm{D}-(+)$-maltose $(H=8.082 ; d f=2$; $p=0.018$ ) concentration of control plants was significantly higher than in radiated plants (Table 3). 90-min radiation only modified the concentration of D-xylitol where $\mathrm{A}+/ \mathrm{B}+$ plants had a significantly higher concentration $(H=6.468 ; d f=2 ; p=0.039)$ (Table 3$)$.

On 60-day-old (BBCH 21) plants (maintenance effect), 30-min radiation produced an higher concentration of sucrose, fructose or maltose on $\mathrm{A}+/ \mathrm{B}+$ plants compared to control or $\mathrm{A}-/ \mathrm{B}+$ radiated plants [sucrose: $72.67 \pm 16.86 \mathrm{nmol} / \mathrm{g}$ dry weight (dw) vs.

Table 3 Mean \pm SE sugar concentration in nmol/g dry weight (dry weight), for each radiation treatment $(\mathrm{A}-/ \mathrm{B}-, \mathrm{A}-/ \mathrm{B}+$ or $\mathrm{A}+/ \mathrm{B}+)$ and $\mathrm{UV}$ exposure time (30, 60 or 90 min daily during 21 days) on 42-day-old plants (BBCH 16; induced effect)

\begin{tabular}{|c|c|c|c|c|c|c|}
\hline UV exposure time & Treatment & D-Xylitol & D-(-)-Fructose & D-Galactose & D-Mannitol & D-Sorbitol \\
\hline $30 \mathrm{~min}$ & $\begin{array}{l}A-B- \\
A-B+ \\
A+B+\end{array}$ & $\begin{array}{l}41.82 \pm 17.15 \mathrm{a} \\
40.38 \pm 12.31 \mathrm{a} \\
26.50 \pm 3.37 \mathrm{a}\end{array}$ & $\begin{array}{l}3.60 \pm 1.38 \mathrm{a} \\
5.20 \pm 1.68 \mathrm{a} \\
2.51 \pm 0.35 \mathrm{a}\end{array}$ & $\begin{array}{c}1.10 \pm 5.46 \mathrm{a} \\
93.31 \pm 32.17 \mathrm{~b} \\
7.68 \pm 5.10 \mathrm{a}\end{array}$ & Non-detectable & Non-detectable \\
\hline $60 \mathrm{~min}$ & $\begin{array}{l}A-B- \\
A-B+ \\
A+B+\end{array}$ & $\begin{array}{c}37.13 \pm 17.06 \mathrm{a} \\
19.27 \pm 9.75 \mathrm{~b} \\
6.37 \pm 0.80 \mathrm{c}\end{array}$ & $\begin{array}{l}4.34 \pm 0.65 \mathrm{a} \\
3.22 \pm 1.66 \mathrm{~b} \\
1.56 \pm 0.25 \mathrm{~b}\end{array}$ & $\begin{array}{l}60.88 \pm 18.25 \mathrm{a} \\
10.23 \pm 4.07 \mathrm{~b} \\
31.99 \pm 9.68 \mathrm{a}\end{array}$ & Non-detectable & $\begin{array}{l}\text { Non-detectable } \\
14.04 \pm 2.28 \\
31.92 \pm 3.59\end{array}$ \\
\hline $90 \min$ & $\begin{array}{l}A-B- \\
A-B+ \\
A+B+\end{array}$ & $\begin{array}{r}6.58 \pm 1.32 \mathrm{~b} \\
13.83 \pm 3.43 \mathrm{~b} \\
20.83 \pm 8.53 \mathrm{a}\end{array}$ & $\begin{array}{l}1.02 \pm 0.19 \mathrm{a} \\
1.32 \pm 0.35 \mathrm{a} \\
1.57 \pm 0.50 \mathrm{a}\end{array}$ & $\begin{array}{l}17.95 \pm 3.78 \mathrm{a} \\
35.09 \pm 13.52 \mathrm{a} \\
40.97 \pm 11.72 \mathrm{a}\end{array}$ & $\begin{array}{l}\text { Non-detectable } \\
36.16 \pm 7.57 \\
62.54 \pm 13.57\end{array}$ & $\begin{array}{l}23.18 \pm 5.38 \mathrm{a} \\
20.92 \pm 4.26 \mathrm{a} \\
23.40 \pm 4.97 \mathrm{a}\end{array}$ \\
\hline UV exposure time & Treatment & Gluconic acid & D-(+)-Glucose & Sucrose & D-(+)-Trehalose & D-(+)-Maltose \\
\hline $30 \mathrm{~min}$ & $\begin{array}{l}A-B- \\
A-B+ \\
A+B+\end{array}$ & Non-detectable & $\begin{array}{l}49.39 \pm 17.10 \mathrm{a} \\
35.37 \pm 7.71 \mathrm{a} \\
47.56 \pm 17.07 \mathrm{a}\end{array}$ & $\begin{array}{r}1466.59 \pm 753.70 a \\
1775.21 \pm 912.99 a \\
432.34 \pm 125.38 a\end{array}$ & Non-detectable & Non-detectable \\
\hline $60 \mathrm{~min}$ & $\begin{array}{l}A-B- \\
A-B+ \\
A+B+\end{array}$ & $\begin{array}{l}\text { Non-detectable } \\
28.39 \pm 7.15 \\
35.70 \pm 6.56\end{array}$ & $\begin{array}{l}\text { Non-detectable } \\
22.55 \pm 2.75 \\
32.08 \pm 1.29\end{array}$ & $\begin{array}{c}274.05 \pm 37.5 \mathrm{a} \\
66.98 \pm 24.55 \mathrm{~b} \\
58.96 \pm 7.19 \mathrm{~b}\end{array}$ & $\begin{array}{l}2558.79 \pm 779.75 a \\
407.68 \pm 184.86 b \\
478.18 \pm 63.98 a\end{array}$ & $\begin{array}{l}1595.64 \pm 474.91 \mathrm{a} \\
346.43 \pm 173.17 \mathrm{~b} \\
330.70 \pm 38.34 \mathrm{~b}\end{array}$ \\
\hline $90 \mathrm{~min}$ & $\begin{array}{l}A-B- \\
A-B+ \\
A+B+\end{array}$ & $\begin{array}{l}32.65 \pm 5.84 a \\
23.20 \pm 3.20 a \\
24.15 \pm 2.08 a\end{array}$ & $\begin{array}{l}24.58 \pm 4.53 a \\
27.57 \pm 3.19 a \\
23.49 \pm 1.94 a\end{array}$ & $\begin{array}{r}82.63 \pm 18.55 \mathrm{a} \\
97.17 \pm 31.58 \mathrm{a} \\
124.69 \pm 17.86 \mathrm{a}\end{array}$ & $\begin{array}{l}670.04 \pm 167.66 a \\
550.58 \pm 178.90 a \\
720.24 \pm 125.78 a\end{array}$ & $\begin{array}{l}438.33 \pm 100.94 a \\
394.89 \pm 124.97 \mathrm{a} \\
522.53 \pm 92.88 \mathrm{a}\end{array}$ \\
\hline
\end{tabular}

Means with different letters within the same sugar and UV radiation time are significantly different are significantly different $(p<0.05)$ 
$21.72 \pm 5.80 \mathrm{nmol} / \mathrm{g}$ for $\mathrm{A}-/ \mathrm{B}-$ and $22.55 \pm 6.76 \mathrm{nmol} / \mathrm{g}$ for $\mathrm{A}-/ \mathrm{B}+(F=7.021 ; d f=2(15) ; p=0.007)$; trehalose: $866.42 \pm 328.11 \mathrm{nmol} / \mathrm{g}$ dw vs. $112.08 \pm 52.92 \mathrm{nmol} / \mathrm{g}$ for A-/B- $(H=6.678 ; d f=2 ; p=0.035)$; maltose $590.39 \pm 223.21 \mathrm{nmol} / \mathrm{g}$ dw vs. $111.59 \pm 45.07 \mathrm{nmol} / \mathrm{g}$ for $\mathrm{A}-/ \mathrm{B}-(H=6.468 ; d f=2 ; p=0.039)]$. An exposure time of 60-min radiation produces no differences (data not shown).

\section{Free amino acids}

Concentration of free amino acid was variable depending mainly of the UV exposure time. On 42-day-old (BBCH 16) plants (induced effect), a radiation time of 30 min daily did not trigger any changes. After an exposure of $60 \mathrm{~min}$ to UV radiation, $\mathrm{L}$-isoleucine concentration was significantly greater in $\mathrm{A}-/ \mathrm{B}-$ plants compared to radiated plants $(H=7.942 ; d f=2 ; p=0.019)$; L-asparagine $(H=6.222$; $d f=2 ; p=0.045)$ and L-tyrosine concentration was higher in control plants compared to $\mathrm{A}+/ \mathrm{B}+$ plants $(H=6.982$; $d f=2 ; p=0.030)$ and L-tryptophan highest accumulation was on $\mathrm{A}-/ \mathrm{B}+$ plants compared to control $\mathrm{A}-/ \mathrm{B}-(H=7.731$; $d f=2 ; p=0.021)$ (Table 4). An exposure time of $90 \mathrm{~min}$ modified the concentration of L-valine $(F=4.753 ; d f=2(15)$; $p=0.025)$, L-Cysteine $(F=5.283 ; d f=2(15) ; p=0.018)$ and L-histidine $(H=6.982 ; d f=2 ; p=0.030)$, where $\mathrm{A}+/ \mathrm{B}+$ plants presented greater concentration that control plants. Also L-tyrosine showed a significantly higher concentration $(H=6.982 ; d f=2 ; p=0.030)$ in control plants compared to radiated ones (Table 4).

On 60-day-old (BBCH 21) plants (maintenance effect) all free amino acids were detectable, being only significantly different $\mathrm{L}$-isoleucine, higher on $\mathrm{A}-/ \mathrm{B}+$ plants radiated for $30 \mathrm{~min}$ compared to control $(24.20 \pm 9.29 \mathrm{nmol} / \mathrm{g} \mathrm{dw}$ vs. $1.06 \pm 0.47 \mathrm{nmol} / \mathrm{g} \mathrm{dw}$ for $\mathrm{A}-/ \mathrm{B}-; H=7.684 ; d f=2$; $p=0.021$ ) (data not shown). An exposure time of 60-min radiation did not trigger any differences (data not shown).

\section{Natural enemies' flight orientation}

A significantly higher number of mirid $N$. tenuis total captures per sticky trap was found inside the cages under $\mathrm{A}-/ \mathrm{B}+$ and $\mathrm{A}+/ \mathrm{B}+$ radiation conditions compared to control $\mathrm{A}-/ \mathrm{B}-$ treatment after $8 \mathrm{~h}$ of insect release $(F=3.970$, $d f=2(15), p=0.041)$, whereas no differences were found among treatments after $2(F=1.060, d f=2(15), p=0.370)$ and $6 \mathrm{~h}(F=1.700, d f=2(15), p=0.216)$ (Fig. 3a). Mirid captures significantly increased with target height under all treatments $(\mathrm{A}+/ \mathrm{B}+: F=33.540, d f=7(47), p<0.001$; $\mathrm{A}-/ \mathrm{B}+: F=14.920, d f=7(47), p<0.001 ; \mathrm{A}-/ \mathrm{B}-$ : $H=28.980, d f=2, p<0.001$ ) (data not shown). Syrphid $S$. rueppellii total captures per sticky trap were higher under $\mathrm{A}+/ \mathrm{B}+$ light conditions compared to control A -/B - after $1 \mathrm{~h}(F=3.270, d f=2(27), p=0.039)$ and compared to $\mathrm{A}-/ \mathrm{B}+$ and control $\mathrm{A}-/ \mathrm{B}-$ after $3 \mathrm{~h}(F=4.950, d f=2(27)$,

Table 4 Mean \pm SE free amino acid concentration in nmol/g dry weight $(\mathrm{dw})$, for each radiation treatment $(\mathrm{A}-/ \mathrm{B}-, \mathrm{A}-/ \mathrm{B}+$ or $\mathrm{A}+/ \mathrm{B}+)$ and UV exposure time (30, 60 or 90 min daily during 21 days) on 42-day-old plants (BBCH 16; induced effect)

\begin{tabular}{|c|c|c|c|c|c|}
\hline UV exposure time & Treatment & L-Alanine & L-Valine & L-Glycine & L-Isoleucine \\
\hline \multirow[t]{3}{*}{$30 \mathrm{~min}$} & $A-B-$ & Non-detectable & $9.167 \pm 5.63 \mathrm{a}$ & $4.94 \pm 3.67 \mathrm{a}$ & $1.35 \pm 0.80 \mathrm{a}$ \\
\hline & $\mathrm{A}-\mathrm{B}+$ & & $13.81 \pm 4.76 \mathrm{a}$ & $4.86 \pm 2.53 \mathrm{a}$ & $1.63 \pm 0.76 \mathrm{a}$ \\
\hline & $\mathrm{A}+\mathrm{B}+$ & & $7.04 \pm 2.00 \mathrm{a}$ & $2.95 \pm 1.05 \mathrm{a}$ & $0.81 \pm 0.26 \mathrm{a}$ \\
\hline \multirow[t]{3}{*}{$60 \mathrm{~min}$} & $\mathrm{~A}-\mathrm{B}-$ & Non-detectable & $3.71 \pm 1.13 \mathrm{a}$ & $7.09 \pm 1.97$ & $4.50 \pm 1.30 \mathrm{a}$ \\
\hline & $\mathrm{A}-\mathrm{B}+$ & & $5.70 \pm 1.92 \mathrm{a}$ & Non-detectable & $0.99 \pm 0.52 b$ \\
\hline & $\mathrm{A}+\mathrm{B}+$ & $8.46 \pm 3.62$ & $5.79 \pm 0.72 \mathrm{a}$ & & $0.81 \pm 0.31 b$ \\
\hline \multirow[t]{3}{*}{$90 \mathrm{~min}$} & $A-B-$ & $7.10 \pm 3.86 \mathrm{a}$ & $2.64 \pm 0.58 b$ & Non-detectable & $1.23 \pm 0.25 \mathrm{a}$ \\
\hline & $\mathrm{A}-\mathrm{B}+$ & $5.87 \pm 1.62 \mathrm{a}$ & $5.87 \pm 1.62 \mathrm{ab}$ & & $0.78 \pm 0.30 \mathrm{a}$ \\
\hline & $\mathrm{A}+\mathrm{B}+$ & $9.34 \pm 3.07 \mathrm{a}$ & $11.07 \pm 2.91 \mathrm{a}$ & & $0.95 \pm 0.41 \mathrm{a}$ \\
\hline UV exposure time & Treatment & L-Cysteine & L-Histidine & L-Tyrosine & L-Tryptophan \\
\hline \multirow[t]{3}{*}{$30 \mathrm{~min}$} & $\mathrm{~A}-\mathrm{B}-$ & $16.07 \pm 6.48 \mathrm{a}$ & Non-detectable & $66.43 \pm 20.13 a$ & $35.18 \pm 14.56 \mathrm{a}$ \\
\hline & $\mathrm{A}-\mathrm{B}+$ & $28.34 \pm 11.54 \mathrm{a}$ & & $70.08 \pm 24.62 \mathrm{a}$ & $23.79 \pm 6.64 a$ \\
\hline & $\mathrm{A}+\mathrm{B}+$ & $11.90 \pm 2.55 \mathrm{a}$ & & $27.44 \pm 6.86 \mathrm{a}$ & $16.52 \pm 3.52 \mathrm{a}$ \\
\hline \multirow[t]{3}{*}{$60 \mathrm{~min}$} & $A-B-$ & $9.53 \pm 3.54 \mathrm{a}$ & Non-detectable & $78.13 \pm 17.39 a$ & $12.57 \pm 2.14 b$ \\
\hline & $\mathrm{A}-\mathrm{B}+$ & $13.76 \pm 8.76 a$ & & $47.40 \pm 36.86 \mathrm{ab}$ & $58.15 \pm 30.95 a$ \\
\hline & $\mathrm{A}+\mathrm{B}+$ & $8.42 \pm 0.96 a$ & $1.39 \pm 0.08$ & $19.69 \pm 3.77 b$ & $26.02 \pm 5.73 \mathrm{ab}$ \\
\hline \multirow[t]{3}{*}{$90 \mathrm{~min}$} & $\mathrm{~A}-\mathrm{B}-$ & $2.34 \pm 0.70 b$ & $0.68 \pm 0.07 b$ & $13.37 \pm 2.28 \mathrm{a}$ & $23.35 \pm 3.92 \mathrm{a}$ \\
\hline & $\mathrm{A}-\mathrm{B}+$ & $10.02 \pm 3.06 \mathrm{ab}$ & $1.46 \pm 0.55 \mathrm{ab}$ & $7.79 \pm 0.82 b$ & $28.92 \pm 9.47 \mathrm{a}$ \\
\hline & $\mathrm{A}+\mathrm{B}+$ & $15.49 \pm 3.86 \mathrm{a}$ & $2.28 \pm 0.64 \mathrm{a}$ & $7.92 \pm 2.10 b$ & $39.77 \pm 12.56 \mathrm{a}$ \\
\hline
\end{tabular}

Means with different letters within the same amino acid and UV radiation time are significantly different $(p<0.05)$ 
$p=0.008$ ) (Fig. 3b). Syrphids were captured at a significantly greater extent at heights over $50 \mathrm{~cm}$ compared to lower heights under all treatments $(\mathrm{A}+/ \mathrm{B}+: U=920.0$, $p=0.023 ; \mathrm{A}-/ \mathrm{B}+: U=1048.0, p=0.004 ; \mathrm{A}-/ \mathrm{B}-$ : $U=1044.0, p=0.003$ ) (data not shown). Total numbers of mirids settled per 21-day-old eggplant previously exposed for 60 min daily to the three UV treatments during 21 days were similar among treatments ( $2 \mathrm{~h}: F=1.086, d f=2(51)$, $p=0.347 ; 24$ h: $H=0.277, d f=2, p=0.871 ; 48$ h: $F=0.060$, $d f=2(51), p=0.938)($ Fig. 3c).

\section{Discussion}

In the present study we demonstrated that different supplementary combinations of UV-A and UV-B in glasshouse environments influenced one of the most important pests worldwide, the whitefly $B$. tabaci, as well as two of its natural enemies, the mirid $N$. tenuis and the syrphid fly $S$. rueppelli. We also showed that UV radiation impacts plant growth and leaf chemistry without modifying fruit production of eggplants, one of the preferred host plants of $B$. tabaci.

The addition of UV-A or UV-B to eggplants had an indirect plant-mediated deterrent effect, reducing the number of whiteflies settled. On 42-day-old eggplants (induced effect), any exposure time or supplementary UV combination significantly reduced the number of whiteflies settled. Indirect effects of plants previously exposed to UV radiation on insect avoidance behavior have previously been reported for aphids (Dáder et al. 2017; Vänninen et al. 2010).

Leaf components were analyzed to correlate any potential indirect effects of UV on the changes we observed on whitefly behavior. A 30-min daily dose of UV radiation did not alter the concentration of carbon or nitrogen, nor any of the detectable amino acids or sugars except for galactose. In addition Dáder et al. $(2014,2017)$ found out on similar assays conducted on eggplants and peppers, that the content of phenolics and carotenoids increased. Leaves of eggplants harvested for biochemical analysis had been also subjected to the different UV treatments and used for the whitefly orientation assays; therefore, the combination of both might have influence the chemical parameters measured here. Plants might have directly responded to whitefly infestation by increasing the production of some secondary metabolites. This reduction on the alighting rate of whiteflies on radiated plants may be due to an increase in the concentration of other secondary metabolites not analyzed in our work (Neugart and Schreiner 2018). UV-B promotes wound and defense signaling pathway partly similar in plants as the one induced by insects via jasmonic acid (Mackerness 2000; Schreiner et al. 2012; Escobar-Bravo et al. 2018). These secondary metabolites and some defense proteins may decrease plants' palatability for phytophagous insects (Izaguirre et al. 2007; Mewis et al. 2012). The reduction in whitefly settlement on radiated plants may be also due to differences in sucrose concentration between the whole leaf tissues and phloem sap (Su et al. 2015, not radiated plants). Sucrose, whose concentration is higher in phloem sap, is known to be a strong feeding stimulant to hemipterans (Berlinger et al. 1983; Mittler et al. 1970). Increasing the duration of UV treatment to $60 \mathrm{~min}$ increased the accumulation of secondary metabolites and leaf thickness (Jansen 2002; Victório et al. 2011). In our work, and after a daily dose of $90 \mathrm{~min}$, plants were severely damaged showing altered leaf morphology, coincident with findings of Almeida et al. (2013) in Oryza sativa plants after UV-B exposure.

On 42-day-old plants (induced effect), a daily 90-min dose of either UV-A or UV-B radiation triggered carbon accumulation and diminished nitrogen when compared to control plants $\mathrm{A}-/ \mathrm{B}-$. This exposure time might have been long enough to severely damage photosynthetic carbon assimilation on A+/B + plants. Under this hypothesis, plants would be able to produce less growing tissue while increasing amino acid content related to host plant resistance to abiotic stresses such as L-valine, L-cysteine or L-histidine. Such increase in amino acid content would occur without altering sugar concentration except for a higher concentration of xylitol. The abiotic stress-associated amino acid proline was not detected on 42-day-old plants (induced effect) (Alexieva et al. 2001; Halford et al. 2015). Histidine, a radiation-associated amino acid or alanine associated with photosynthesis was only detectable under longer radiation exposures (D'Mello 2015; Monselise et al. 2015).

When these plants were allowed to grow after the completion of UV treatments for 18 more days under normal glasshouse conditions until whitefly experiment (maintenance effect), 30-min daily UV radiation did not affect whitefly settlement. Leaf parameters were similar and only the amino acid isoleucine was higher on $\mathrm{A}-/ \mathrm{B}+$ compared to control, as well as $\mathrm{A}+\mathrm{B}+$ plants had higher sucrose, trehalose or maltose than control. Plants were able to recover from radiation. Whiteflies preferred to settle on $\mathrm{A}+/ \mathrm{B}+$ plants previously radiated during $60 \mathrm{~min}$. This may be due to the size, since these plants were bigger and probably whiteflies had easier access to alight on leaves of the tallest and largest plants. Moreover, leaves were thicker and had higher content of carbon, while no differences were present in the amino acid or sugar content when comparing to control plants although the preference might provoked by non-analyzed compounds. Leaf thickness, in this case, may not be that important for whitefly settlement, because no differences could be appreciated on settlement between $A+/ B+$ and $\mathrm{A}-/ \mathrm{B}-$. As a whole, no differences on settlement were observed on 60-day-old plants (maintenance effect), meaning that the UV effect present on 42-day-old plants (induced 
effect) may be transient. On 60-day-old plants (maintenance effect), 30-min radiation increased concentration of disaccharides on $\mathrm{A}+/ \mathrm{B}+$ plants even though a 60 -min radiation did not alter their concentration on $\mathrm{A}+/ \mathrm{B}+$ radiated plants. As stated on Sullivan et al. (2003), UV-A increases the assimilation of carbon, and in this case 60-min radiation was an exposure time long enough for the carbon concentration to increase although no differences could be seen in the sugar or amino acid content.

Supplemental UV modified eggplant size and morphology mainly in the first period of the crop circle (seedling to flowering, BBCH 11-52), whereas, as expected, increasing exposure time to UV radiation promoted deeper changes in the plant. When host plants were studied right after the radiation treatments (induced effect), the only physiological characteristic that was altered after a daily 30 -min radiation was fresh weight. This result indicates that this UV exposure period is either not long enough to produce significant alterations in the plant or the plant machinery is able to counteract the effect of radiation (Verdaguer et al. 2017). These observations differ with the ones presented by Kittas et al. (2006), where 45 days under high UV-B radiation caused a decrease in leaf area index or stem length probably due to the UV daily dose. However, in our work we exposed plants to UV for just $30 \mathrm{~min}$, while Kittas et al. (2006) used all day UV exposure in their work.

When radiation was increased up to $60 \mathrm{~min}$, fresh and dry weights were altered for plants under UV-B radiation only. Growth traits of plants radiated with both UV-A and UV-B were similar to control plants; this may be due to the ameliorating process that PAR light and the blue wavelength of UV-A have on plants (Adamse and Britz 1992; Krizek 2004; Peng et al. 1995). A maximum daily exposure of $90 \mathrm{~min}$ was extremely harmful for eggplants, UV decreased shoot fresh and dry weight and stem length, indicating that in this case UV-A and PAR supplemental radiation were not able to mitigate the detrimental effects of UV-B radiation.

Plants exposed to the different UV treatments were allowed to grow for another 18 days away from UV radiation (maintenance effect). A previous daily dose of $30 \mathrm{~min}$ did not cause significant differences in any parameter; therefore, plants were able to recover from the stress. However, 60-min radiation induced $\mathrm{A}+/ \mathrm{B}+$ plants to have more fresh weight probably due to the natural UV-A and PAR light ameliorating effect in absence of UV-B. Another possible cause of the increased fresh weigh is the UV-A stimulatory effect on plant biomass production (Bernal et al. 2013; Caldwell et al. 1994; Dáder et al. 2014; Kataria et al. 2013; Štroch et al. 2015; Tezuka et al. 1993, 1994; Turnbull et al. 2013). Hence the stimulatory effect of UV-A and PAR was only transiently active as 130-day-old plants were all similar regardless of the radiation treatment. Nevertheless, 60 -min radiation caused leaves from $\mathrm{A}+/ \mathrm{B}+$ treatment to be thicker. No differences were appreciated in leaf area. Therefore, the changes were caused by the differences in dry mass. $\mathrm{A}+/ \mathrm{B}+$ leaves were heavier probably due to the increased carbon assimilation after the radiation and the stimulation that UV-A has on adaxial epidermal thickness and cell length (Verdaguer et al. 2012).

Fruit production and number of flowers were similar for all treatments independently of the duration of UV. This contrasts with previous works regarding the relationship between crop yield and ultraviolet radiation on eggplants, cucumbers (Cucumis sativus) or Phasaeolus mungo L. (Abd El-Aal et al. 2018; Jayakumar et al. 2003; Kittas et al. 2006), probably because they applied UV radiation during the whole crop circle as opposed to us.

Behavioral activities of natural enemies are influenced by light environment in a species-specific manner (Chiel et al. 2006; Doukas and Payne 2007; Johansen et al. 2011; Legarrea et al. 2012b). There is a large body of literature highlighting neutral effects of UV-deficient environments on natural enemies, mostly hymenopteran parasitoids, and similar activity has been reported for Aphidius matricariae Haliday, Aphidius colemani Viereck (Hymenoptera: Aphidiinae) or Diglyphus isaea Walker (Hymenoptera: Eulophidae), and mite Amblyseius swirskii Athias-Henriot (Acari: Phytoseiidae) (Chiel et al. 2006; Chyzik et al. 2003; Doukas and Payne 2007; Legarrea et al. 2012b). Most parasitoids exploit olfactory cues and can orient to vegetation infested with their hosts similarly under light or dark conditions, and this strategy could also be followed by syrphids (Michaud and Mackauer 1995; Storeck et al. 2000).

On the contrary, Eretmocerus mundus Mercet (Hymenoptera: Aphelinidae) or Orius laevigatus (Fieber) (Hemiptera: Anthocoridae) show reduced orientation and host location under diminished UV radiation (Chiel et al. 2006; Legarrea et al. 2012b), which would agree with our S. rueppellii tests where captures under UV-enriched environment doubled compared to control conditions. Results cannot be completely compared with our previous findings showing similar foraging success under deficient- and enriched-UV environments (Dáder et al. 2015). Target election may be behind this variety of responses, with syrphids localizing worse the inert yellow traps without supplemental UV light, an election that is purely based on the color of the target (visual cues). However, when the target was a plant infested with prey, relevant resource-indicating key volatiles were also present (olfactory cues), and $S$. rueppellii could perform well even when the enclosure lacked UV radiation (Dáder et al. 2015). The flight pattern and the contrast caused by the yellow area of the sticky trap could have also influenced the response, as they syrphids significantly more captured at heights over $50 \mathrm{~cm}$.

Similarly to syrphids, a significantly higher number of $N$. tenuis was captured under UV-B radiation, and mirid 
captures significantly increased with target height. Mirids did not show any particular preference to settle on any of the different plants of the indirect effect assay. Physicochemical characteristics of plant surface play a key role on arthropod election; however, we were not able to analyze the chemical profile of eggplants this time as we did for the whitefly experiment (Vänninen et al. 2010). Developmental stage could also condition the response (Ben-Yakir and Fereres 2016). Nesidiocoris tenuis is a zoophytophagous mirid. Nymphs prefer to feed on plants compared to the proteinrich diet coming from preys during adulthood (Puysseleyr et al. 2013). It is important to state that we did not evaluate the presence of black spots on plants due to mirid feeding so we are not certain if adults fed or not on the eggplants previously grown under the different UV light regimes.

In conclusion, supplementary UV radiation could be used to reduce whitefly infestation in glasshouses at the early stages of plant development without detrimental effects on crop yield or beneficial orientation. Results for whiteflies, syrphids and mirids show that any generalization about the effect of UV on arthropods may lead to inadequate interpretations. A daily supplementary combination of UV-A and UV-B radiation for 30 min during 21 days could be an effective preventive strategy to reduce whitefly infestation in glasshouses without detrimental effects on eggplant production. However, longer exposures to UV radiation may have detrimental effect on whiteflies and on their host plants. Natural enemies that rely most on their vision to find a host may suffer similar difficulties as pests when glasshouses lack UV radiation (Chiel et al. 2006). It still remains to be determined whether $S$. rueppellii and $N$. tenuis use additional cues but our data suggest that both insects could maintain the efficacy under UV-deficient environment. From our point of view, visual and chemical cues involved in dispersal are an unexplored topic that deserves further research for whiteflies and natural enemies, and more work needs to be carried out to identify those beneficial arthropods that are most compatible with each UV light regime.

\section{Author contributions}

IPR, EG, AM, PM, EV and AF conceived and designed research; IPR and EG conducted the experiments; IPR, EG, AM, PM, EV and AF analyzed the data; all authors wrote and reviewed the manuscript.

Acknowledgements The authors are indebted to Sandra Pla, Marina Morente, Irene Ontiveros, Andrea Wanumen, Miriam Gurpegui and Ignacio Morales for their assistance in the laboratory experiments. This work was funded by the Spanish Ministry of Economy and Competitiveness (AGL2013-47603-C2-1-R to E. Viñuela and P. Medina and AGL2013-47603-C2-2-R to A. Fereres). A. Fereres, A. Moreno, P. Medina and E. Viñuela are members of the Associate unit IVAS
(CSIC-UPM): Control of insect vectors of viruses in horticultural sustainable systems.

\section{Compliance with ethical standards}

Conflict of interest The authors have declared that no conflict of interest exists.

Human and animal rights This article does not contain any studies with human participants or animals (vertebrates) performed by any of the authors.

\section{References}

Abd El-Aal HA, Rizk AM, Mousa IE (2018) Evaluation of new greenhouse covers with modified light regime to control cotton aphid and cucumber (Cucumis sativus L.) productivity. Crop Prot 107:64-70. https://doi.org/10.1016/j.cropro.2018.01.011

Acosta-Quezada PG, Riofrío-Cuenca T, Rojas J, Vilanova S, Plazas M, Prohens J (2016) Phenological growth stages of tree tomato (Solanum betaceum Cav.), an emerging fruit crop, according to the basic and extended BBCH scales. Sci Hortic 199:216-223. https ://doi.org/10.1016/j.scienta.2015.12.045

Adamse P, Britz SJ (1992) Amelioration of UV-B damage under high irradiance. I: role of photosynthesis. photochem. Photochem Photobiol 56:645-650. https://doi.org/10.1111/j.1751-1097.1992. tb02216.x

Alexieva V, Sergiev I, Mapelli S, Karanov E (2001) The effect of drought and ultraviolet radiation on growth and stress markers in pea and wheat. Plant Cell Environ 24:1337-1344. https://doi.org /10.1046/j.1365-3040.2001.00778.x

Almeida SL, Schmidt ÉC, Pereira DT, Kreusch M, Felix MRL, Osorio LKP, Martins RP, Latini A, Ramlov F, Chow F, Maraschin M, Rodrigues AC, Bouzon ZL (2013) Effect of ultraviolet-B radiation in laboratory on morphological and ultrastructural characteristics and physiological parameters of selected cultivar of Oryza sativa L. Protoplasma 250:1303-1313. https://doi.org/10.1007/s0070 9-013-0512-0

Antignus Y, Lapidot M, Hadar D, Messika Y, Cohen S (1998) Ultraviolet-absorbing screens serve as optical barriers to protect crops from virus and insect pests. J Econ Entomol 91:1401-1405. https ://doi.org/10.1093/jee/91.6.1401

Ben-Yakir D, Fereres A (2016) The effects of UV radiation on arthropods: a review of recent publications (2010-2015). Acta Hortic. https://doi.org/10.17660/ActaHortic.2016.1134.44

Berlinger MJ, Magal Z, Benzioni A (1983) The importance of $\mathrm{pH}$ in food selection by the tobacco whitefly, Bemisia tabaci. Phytoparasitica 11:151. https://doi.org/10.1007/BF02980686

Bernal M, Llorens L, Badosa J, Verdaguer D (2013) Interactive effects of UV radiation and water availability on seedlings of six woody Mediterranean species. Physiol Plant 147:234-247. https://doi. org/10.1111/j.1399-3054.2012.01660.x

Caldwell MM, Flint SD, Searles PS (1994) Spectral balance and UV-B sensitivity of soybean: a field experiment. Plant Cell Environ 17:267-276. https://doi.org/10.1111/j.1365-3040.1994.tb00292.x

Chiel E, Messika Y, Steinberg S, Antignus Y (2006) The effect of UVabsorbing plastic sheet on the attraction and host location ability of three parasitoids: Aphidius colemani, Diglyphus isaea and Eretmocerus mundus. BioControl 51:65-78. https://doi.org/10.1007/ s10526-005-8667-z

Chyzik R, Dobrinin S, Antignus Y (2003) Effect of a UV-deficient environment on the biology and flight activity of Myzus persicae 
and its hymenopterous parasite Aphidius matricariae. Phytoparasitica 31:467-477. https://doi.org/10.1007/BF02979740

Coombe PE (1982) Visual behaviour of the greenhouse whitefly, Trialeurodes vaporariorum. Physiol Entomol 7:243-251. https://doi. org/10.1111/j.1365-3032.1982.tb00297.x

Corrales AR, Nebauer SG, Carrillo L, Fernández-Nohales P, Marqués J, Renau-Morata B, Granell A, Pollmann S, Vicente-Carbajosa J, Molina RV, Medina J (2014) characterization of tomato cycling dof factors reveals conserved and new functions in the control of flowering time and abiotic stress responses. J Exp Bot 65:9951012. https://doi.org/10.1093/jxb/ert451

D'Mello JPF (ed) (2015) Amino acids in higher plants. CABI, Wallingford

Dáder B, Gwynn-Jones D, Moreno A, Winters A, Fereres A (2014) Impact of UV-A radiation on the performance of aphids and whiteflies and on the leaf chemistry of their host plants. J Photochem Photobiol B 138:307-316. https://doi.org/10.1016/j.jphot obiol.2014.06.009

Dáder B, Plaza M, Fereres A, Moreno A (2015) Flight behaviour of vegetable pests and their natural enemies under different ultraviolet-blocking enclosures. Ann Appl Biol 167(1):116-126. https ://doi.org/10.1111/aab.12213

Dáder B, Moreno A, Gwynn-Jones D, Winters A, Fereres A (2017) Aphid orientation and performance in glasshouses under different UV-A/UV-B radiation regimes. Entomol Exp Appl 163(3):344353. https://doi.org/10.1111/eea.12583

Demukra PV, Abdala G, Baldwin IT, Ballaré CL (2010) Jasmonatedependent and independent pathways mediate specific effects of solar ultraviolet $\mathrm{B}$ radiation on leaf phenolics and antiherbivore defense. Plant Physiol 152:1084-1095. https://doi.org/10.1104/ pp.109.148999

Dhomse SS, Kinnison D, Chipperfield MP, Salawitch RJ, Cionni I, Hegglin MI, Abraham NL, Akiyoshi H, Archibald AT, Bednarz EM, Bekki S, Braesicke P, Butchart N, Dameris M, Deushi M, Frith S, Hardiman SC, Hassler B, Horowitz LW, Hu R-M, Jöckel P, Josse B, Kirner O, Kremser S, Langematz U, Lewis J, Marchand M, Lin M, Mancini E, Marécal V, Michou M, Morgenstern O, O’Connor FM, Oman L, Pitari G, Plummer DA, Pyle JA, Revell LE, Rozanov E, Schofield R, Stenke A, Stone K, Sudo K, Tilmes S, Visioni D, Yamashita Y, Zeng G (2018) Estimates of ozone return dates from chemistry-climate model initiative simulations. Atmos Chem Phys 18:8409-8438. https://doi.org/10.5194/ acp-18-8409-2018

Díaz B, Fereres A (2007) Ultraviolet-blocking materials as a physical barrier to control insect pests and pathogens in protected crops. Pest Technol 1(2):85-95

Doukas D, Payne CC (2007) The use of ultraviolet-blocking films in insect pest management in the UK; effects on naturally occurring arthropod pest and natural enemy populations in a protected cucumber crop. Ann Appl Biol 151:221-231. https://doi.org/10. 1111/j.1744-7348.2007.00169.x

Dwivedi A, Tripathi AK, Singh J, Pal MK (2018) Ultraviolet radiation (UVR): an introduction. Photocarcinogenesis \& photoprotection. Springer, Berlin. https://doi.org/10.1007/978-981-10-5493-8_1

Enciso YJ, Santa Cruz LA, Hackney Price JF (2018) Scrutinizing the effects of UV-C radiation on developmental timing and adult morphology of Drosophila melanogaster. J Ariz Nev Acad Sci 47(2):5. https://doi.org/10.2181/036.047.0206

Escobar-Bravo R, Cheng G, Kim HK, Grosser K, van Dam NM, Leiss KA, Klinkhamer PGL (2018) Ultraviolet radiation exposure time and intensity modulate tomato resistance against herbivory through activation of the jasmonic acid signaling. J Exp Bot. https ://doi.org/10.1093/jxb/ery347

Foster JJ, Sharkey CR, Gaworska AVA, Roberts NW, Whitney HM, Partridge JC (2014) Bumblebees learn polarization patterns. Curr Biol 24:1415-1420. https://doi.org/10.1016/j.cub.2014.05.007
González JA, Rosa M, Parrado MF, Hilal M, Prado FE (2009) Morphological and physiological responses of two varieties of a highland species (Chenopodium quinoa Willd.) growing under nearambient and strongly reduced solar UV-B in a lowland location. J Photochem Photobiol B 96:144-151. https://doi.org/10.1016/j. jphotobiol.2009.05.003

Halford NG, Curtis TY, Chen Z, Huang J (2015) Effects of abiotic stress and crop management on cereal grain composition: implications for food quality and safety. J Exp Bot 66:1145-1156. https:// doi.org/10.1093/jxb/eru473

Izaguirre MM, Mazza CA, SvatoŠ A, Baldwin IT, Ballaré CL (2007) Solar ultraviolet-B radiation and insect herbivory trigger partially overlapping phenolic responses in Nicotiana attenuata and Nicotiana longiflora phenolics. Ann Bot 99:103-109. https://doi. org/10.1093/aob/mcl226

Jansen MAK (2002) Ultraviolet-B radiation effects on plants: induction of morphogenic responses. Physiol Plant 116:423-429. https://doi. org/10.1034/j.1399-3054.2002.1160319.x

Jayakumar M, Amudha P, Kulandaivelu G (2003) Changes in growth and yield of Phaseolus mungo L. induced by UV-A and UV-B enhanced radiation. J Plant Biol 46:59-61. https://doi. org/10.1007/BF03030303

Johansen N, Vänninen I, Pinto DM, Nissinen A, Shipp L (2011) In the light of new greenhouse technologies: 2. Direct effects of artificial lighting on arthropods and integrated pest management in greenhouse crops. Ann Appl Biol 159:1-27. https://doi.org/10.1 111/j.1744-7348.2011.00483.x

Kataria S, Guruprasad KN, Ahuja S, Singh B (2013) Enhancement of growth, photosynthetic performance and yield by exclusion of ambient UV components in $\mathrm{C} 3$ and $\mathrm{C} 4$ plants. J Photochem Photobiol B 127:140-152. https://doi.org/10.1016/j.jphotobiol .2013 .08 .013

Kirchner SM, Döring TF, Saucke H (2005) Evidence for trichromacy in the green peach aphid, Myzus persicae (Sulz.) (Hemiptera: Aphididae). J Insect Physiol 51:1255-1260. https://doi. org/10.1016/j.jinsphys.2005.07.002

Kittas C, Tchamitchian M, Katsoulas N, Karaiskou P, Papaioannou C (2006) Effect of two UV-absorbing greenhouse-covering films on growth and yield of an eggplant soilless crop. Sci Hortic 110:30 37. https://doi.org/10.1016/j.scienta.2006.06.018

Krizek DT (2004) Influence of PAR and UV-A in determining plant sensitivity and photomorphogenic responses to UV-B radiation. Photochem Photobiol 79:307-315. https://doi. org/10.1111/j.1751-1097.2004.tb00013.x

Legarrea S, Diaz BM, Plaza M, Barrios L, Morales I, Viñuela E, Fereres A (2012a) Diminished UV radiation reduces the spread and population density of Macrosiphum euphorbiae (Thomas) [Hemiptera: Aphididae] in lettuce crops. Hortic Sci 39:74-80

Legarrea S, Weintraub PG, Plaza M, Vinuela E, Fereres A (2012b) Dispersal of aphids, whiteflies and their natural enemies under photoselective nets. BioControl 57:523-532. https://doi.org/10.1007/ s10526-011-9430-2

Legarrea S, Velázquez E, Aguado P, Fereres A, Morales I, Rodríguez D, Estal PD, Viñuela E (2014) Effects of a photoselective greenhouse cover on the performance and host finding ability of Aphidius ervi in a lettuce crop. BioControl 59:265-278. https:// doi.org/10.1007/s10526-014-9564-0

Mackerness SAH (2000) Plant responses to ultraviolet-B (UV-B: 280$320 \mathrm{~nm}$ ) stress: what are the key regulators? Plant Growth Regul 32:27-39. https://doi.org/10.1023/A:1006314001430

Matthews REF, Hull R, Matthews REF (2002) Matthews' plant virology. Academic Press, San Diego

McKenzie RL, Aucamp PJ, Bais AF, Björ LO, Ilyas M (2007) Changes in biologically-active ultraviolet radiation reaching the Earth's surface. Photochem Photobiol Sci 6:218-231. https://doi. org/10.1039/B700017K 
Mellor HE, Bellingham J, Anderson M (1997) Spectral efficiency of the glasshouse whitefly Trialeurodes vaporariorum and Encarsia formosa its hymenopteran parasitoid. Entomol Exp Appl 83:11-20. https://doi.org/10.1046/j.1570-7458.1997.00152.x

Mewis I, Schreiner M, Nguyen CN, Krumbein A, Ulrichs C, Lohse M, Zrenner R (2012) UV-B irradiation changes specifically the secondary metabolite profile in broccoli sprouts: induced signaling overlaps with defense response to biotic stressors. Plant Cell Physiol 53:1546-1560. https://doi.org/10.1093/pcp/pcs096

Michaud JP, Mackauer M (1995) The use of visual cues in host evaluation by aphidiid wasps. Entomol Exp Appl 74:267-275. https:// doi.org/10.1111/j.1570-7458.1995.tb01900.x

Mittler TE, Dadd RH, Daniels SC (1970) Utilization of different sugars by the aphid Myzus persicae. J Insect Physiol 16:1873-1890. https ://doi.org/10.1016/0022-1910(70)90234-9

Monselise EBI, Levkovitz A, Kost D (2015) Ultraviolet radiation induces stress in etiolated Landoltia punctata, as evidenced by the presence of alanine, a universal stress signal: a $15 \mathrm{~N}$ NMR study. Plant Biol 17:101-107. https://doi.org/10.1111/plb.12198

Mound LA (1962) Studies on the olfaction and colour sensitivity of Bemisia tabaci (Genn.) (Homoptera, Aleyrodidae). Entomol Exp Appl 5:99-104. https://doi.org/10.1111/j.1570-7458.1962.tb005 71.x

Neugart S, Schreiner M (2018) UVB and UVA as eustressors in horticultural and agricultural crops. Sci Hortic 234:370-381. https:// doi.org/10.1016/j.scienta.2018.02.021

Oliveira MRV, Henneberry TJ, Anderson P (2001) History, current status, and collaborative research projects for Bemisia tabaci. Crop Prot 20:709-723. https://doi.org/10.1016/S0261-2194(01)00108-9

Onzo A, Sabelis MW, Hanna R (2010) Effects of ultraviolet radiation on predatory mites and the role of refuges in plant structures. Environ Entomol 39:695-701. https://doi.org/10.1603/EN09206

Paul ND, Moore JP, McPherson M, Lambourne C, Croft P, Heaton JC, Wargent JJ (2012) Ecological responses to UV radiation: interactions between the biological effects of UV on plants and on associated organisms. Physiol Plant 145:565-581. https://doi.org /10.1111/j.1399-3054.2011.01553.x

Peng S, Ingram KT, Neue HU, Ziska LH (1995) Climate change and rice. International Rice Research Institute, Springer, Berlin

Puysseleyr VD, Man SD, Höfte M, Clercq PD (2013) Plantless rearing of the zoophytophagous bug Nesidiocoris tenuis. BioControl 58:205-213. https://doi.org/10.1007/s10526-012-9486-7

Raviv M, Antignus Y (2004) Invited review: UV radiation effects on pathogens and insect pests of greenhouse-grown crops. Photochem Photobiol 79:219-226. https://doi.org/10.1562/SI-03-14.1

Rozema J, van de Staaij J, Björn LO, Caldwell M (1997) UV-B as an environmental factor in plant life: stress and regulation. Trends Ecol Evol 12:22-28. https://doi.org/10.1016/S0169 $-5347(96) 10062-8$

Schreiner M, Mewis I, Huyskens-Keil S, Jansen MAK, Zrenner R, Winkler JB, O'Brien N, Krumbein A (2012) UV-B-induced secondary plant metabolites-potential benefits for plant and human health. Crit Rev Plant Sci 31:229-240. https://doi.org/10.1080/07352 689.2012.664979

Short BD, Janisiewicz W, Takeda F, Leskey TC (2018) UV-C irradiation as a management tool for Tetranychus urticae on strawberries. Pest Manag Sci 74:2419-2423. https://doi.org/10.1002/ps.5045

Solomon S (1999) Stratospheric ozone depletion: a review of concepts and history. Rev Geophys 37:275-316. https://doi. org/10.1029/1999RG900008

Storeck A, Poppy GM, van Emden HF, Powell W (2000) The role of plant chemical cues in determining host preference in the generalist aphid parasitoid Aphidius colemani. Entomol Exp Appl 97:41-46. https://doi.org/10.1046/j.1570-7458.2000.00714.x

Štroch M, Materová Z, Vrábl D, Karlický V, Šigut L, Nezval J, Špunda V (2015) Protective effect of UV-A radiation during acclimation of the photosynthetic apparatus to UV-B treatment. Plant Physiol Biochem 96:90-96. https://doi.org/10.1016/j.plaphy.2015.07.017

Su Q, Preisser EL, Zhou XM, Xie W, Liu BM, Wang SL, Wu QJ, Zhang YJ (2015) Manipulation of host quality and defense by a plant virus improves performance of whitefly vectors. J Econ Entomol 108:11-19. https://doi.org/10.1093/jee/tou012

Sullivan JH, Gitz DG, Peek MS, McElrone AJ (2003) Response of three eastern tree species to supplemental UV-B radiation: leaf chemistry and gas exchange. Agric For Meteorol 120:219-228. https://doi.org/10.1016/j.agrformet.2003.08.016

Tezuka T, Hotta T, Watanabe I (1993) Growth promotion of tomato and radish plants by solar UV radiation reaching the Earth's surface. J Photochem Photobiol B 19:61-66. https://doi.org/10.1016/10111344(93)80094-P

Tezuka T, Yamaguchi F, Ando Y (1994) Physiological activation in radish plants by UV-A radiation. J Photochem Photobiol B 24:3340. https://doi.org/10.1016/1011-1344(94)07006-7

Turnbull TL, Barlow AM, Adams MA (2013) Photosynthetic benefits of ultraviolet-A to Pimelea ligustrina, a woody shrub of subalpine Australia. Oecologia 173:375-385. https://doi.org/10.1007/ s00442-013-2640-9

Vänninen I, Pinto DM, Nissinen AI, Johansen NS, Shipp L (2010) In the light of new greenhouse technologies: 1. Plant-mediated effects of artificial lighting on arthropods and tritrophic interactions. Ann Appl Biol 157:393-414. https://doi.org/10.111 1/j.1744-7348.2010.00438.x

Verdaguer D, Llorens L, Bernal M, Badosa J (2012) Photomorphogenic effects of UVB and UVA radiation on leaves of six Mediterranean sclerophyllous woody species subjected to two different watering regimes at the seedling stage. Environ Exp Bot 79:66-75. https:// doi.org/10.1016/j.envexpbot.2012.01.008

Verdaguer D, Jansen MAK, Llorens L, Morales LO, Neugart S (2017) UV-A radiation effects on higher plants: exploring the known unknown. Plant Sci 255:72-81. https://doi.org/10.1016/j.plant sci.2016.11.014

Victório CP, Leal-Costa MV, Schwartz Tavares E, Machado Kuster R, Salgueiro Lage CL (2011) Effects of supplemental UV-A on the development, anatomy and metabolite production of Phyllanthus tenellus cultured in vitro. Photochem Photobiol 87:685-689. https ://doi.org/10.1111/j.1751-1097.2011.00905.x

Vile D, Garnier É, Shipley B, Laurent G, Navas ML, Roumet C, Lavorel S, Díaz S, Hodgson JG, Lloret F, Midgley GF, Poorter H, Rutherford MC, Wilson PJ, Wright IJ (2005) Specific leaf area and dry matter content estimate thickness in laminar leaves. Ann Bot 96:1129-1136. https://doi.org/10.1093/aob/mci264

WMO, UNEP, NOAA, NASA, European Commission (2018) Executive summary: scientific assessment of ozone depletion: 2018 World Meteorological Organization, United Nations Environment Programme, National Oceanic and Atmospheric Administration, National Aeronautics, Space Administration European Commission, p 58

Publisher's Note Springer Nature remains neutral with regard to jurisdictional claims in published maps and institutional affiliations. 